\title{
Gynecological Management of Neuropathic Pain
}

\author{
Frank F. TU, MD, MPH ${ }^{a, b}$, Kevin HELLMAN, PhD ${ }^{a, c}$, and Miroslav BACKONJA, MD ${ }^{d}$ \\ a NorthShore University HealthSystem Dept. of Obstetrics and Gynecology \\ b University of Chicago Pritzker School of Medicine Dept. of Obstetrics and Gynecology \\ c Dept. of Neurobiology \\ d University of Wisconsin-Madison. Dept. of Neurology and Anesthesiology
}

\begin{abstract}
Obstetrician/gynecologists often are the initial management clinicians for pelvic neuropathic pain. While treatment may require comprehensive team management and consultation with other specialists, there a few critical and basic steps that can be performed on an office visit that offer the opportunity to significantly improve quality of life in this patient population. A key first step is a thorough clinical examination to physically map the pain site and identify potentially involved nerves. Only limited evidence exists on how best to manage neuropathic pain, but generally a combination of surgical, manipulative or pharmacological methods should be considered. Experimental methods for more precisely characterizing the nature of the nerve dysfunction exist to diagnose and treat neuropathic pain, but additional scientific evidence is needed to unanimously recommend these options. In the meantime, an approach adopted from guidelines of the International Association for Study of Pain tailored for gynecological pain is suggested.
\end{abstract}

\section{Keywords}

Neuropathic Pain; Pudendal Neuralgia; Chronic Pain

\section{Background}

Modern obstetrical care has obviously progressed with the addition of pain medicine to management of labor, but application to gynecological pain receives less attention.

Neuropathic pain is defined as a pain arising as a direct consequence of a lesion or disease affecting the sensory component of the nervous system according to the Neuropathic Pain Special Interest group of International Association for the Study of Pain definition. ${ }^{1}$ While there are no uniform definitions on magnitude and duration, this type of pain is severe ( $>5$ of $0-10$ with 10 being worst possible) and persists longer than superficial wounds (weeks to decades). Words used to describe the perception of neuropathic pain include "electric

(C) 2011 Mosby, Inc. All rights reserved.

Corresponding author: Dr. Frank F. Tu, Dept. of Ob/Gyn, Walgreen's Bldg 1507, Evanston Hospital, 2650 Ridge Ave., Evanston, IL, USA 60201, Work: 847570 2521, Cell: 312208 4835, Home: 847866 7526, Fax: 847570 1846, ftu@ northshore.org.

No reprints will be made available

DISCLOSURE: At the time of the publication Dr. Tu will have consulted for Ethicon Endo-Surgery (May 2011). The other authors have reported no potential conflicts

Publisher's Disclaimer: This is a PDF file of an unedited manuscript that has been accepted for publication. As a service to our customers we are providing this early version of the manuscript. The manuscript will undergo copyediting, typesetting, and review of the resulting proof before it is published in its final citable form. Please note that during the production process errors may be discovered which could affect the content, and all legal disclaimers that apply to the journal pertain. 
shock", "dull", "itching", and "burning." The challenge of exclusively confirming that pain is of neuropathic origin has led to the clinical guideline that it be graded as "definite, probable, or possible" neuropathic pain. Cardinal symptoms of neuropathic pain include hyperalgesia (increased sensitivity to pain) and allodynia (increased sensitivity to touch), although these are nonspecific. ${ }^{2}$ While injured tissue is expected to recover following the resolution of the initial acute trauma, persistent changes in sensory processing (i.e. spinal neuron responsiveness) can maintain a state of severe pain. Women unfortunately face many abdominal/pelvic insults that can cause probable neuropathic pain. Estimates of chronic pain following caesarean or vaginal delivery range from 10-20\% while gynecological procedures may be associated with a 5-32\% risk \%. ${ }^{3-8}$ Plausibly, sex-dependent physiological processes and neuroanatomical differences between women and men underlie the high risk of chronic pain following pelvic surgery, and indeed, between gender comparisons following surgical procedures generally suggest women experience higher levels of perioperative pain, which likely reflects some component of neuropathic pain. ${ }^{9-13}$

The study of pelvic neuropathic pain has likely been hampered by the wide, and confusing differential diagnosis to consider for abdomino-pelvic pain presentations. Consequently, we will make recommendations for clinical practice based on more clear-cut disorders such as diabetic neuropathy. One unique pelvic neuropathy that we will touch on is pudendal nerve dysfunction, which appears to result from the convergence of myofascial dysfunction and anatomical nerve compression between the sacrospinous and sacrotuberous ligaments. ${ }^{14}$ However, it too remains a challenge to characterize, as pudendal neuropathy is still not a discrete entity, but one that appears to present often with concomitant pelvic floor spasm.

The most important characteristic to recognize is that neuropathic pain can be reliably detected using psychophysical clinical examination rather than using other diagnostic modalities (electrical, magnetic resonance, $x$-ray, etc) beyond the exam. ${ }^{1}$ At the most peripheral edge, mechanical and chemical receptors on sensory fibers, termed nociceptors, convey electrical signals to the spinal cord that indicate the presence of a painful stimulus. ${ }^{15}$ Tissue is differentially innervated by multiple sensory fibers of varying sizes and properties, and different kinds of painful stimuli are processed by discrete sensory fiber types. ${ }^{16}$ Indeed, different kinds of trauma can produce damage to specific fiber types. While deficits can be identified roughly by description, more precise characterization can be accomplished through quantitative sensory testing (QST), which evaluates a patient's pain response to pressure, electrical stimulation or heat/cold evoked stimulation. We and others have applied these measures to characterize a limited subset of pelvic pain conditions which may have neuropathic components. ${ }^{17-20}$ Consistent with this idea, localization of the damaged nerve combined with psychophysiological characterization represent a standard component of the diagnostic work-up neuropathic pain as described below.

The second most important principle in diagnosing neuropathic pain is recognizing it often involves changes in central nervous system processing, not just peripheral tissues. ${ }^{21-22}$ With central aberrations in pain modulation and processing, symptoms can present out of proportion to the degree of tissue insult, and may not correspond to tight dermatomal distributions. In animal models multiple studies show that a completely peripheral neuropathy (such as sciatic nerve ligation) is maintained by changes in supraspinal neurons. ${ }^{23-24}$ Stimulation of specific brain sites can provide profound analgesia and has spurred the development of brain stimulation strategies for alleviating pain in patients with the most severe forms of pain. ${ }^{25-26}$ Corollary to this principle is that neuropathic pain affects sleep and disposition and therefore therapies that improve quality of life from neuropathic pain must rectify brain-wide problems. ${ }^{27-28}$ Patients exhibiting evidence of central sensitization may need treatment with centrally acting neuromodulatory medications labeled for use as antidepressants, anticonvulsants, and sedative-hypnotics, despite the 
appearance of a peripheral problem. With these principles in mind, we describe the approach to diagnosis and treatment of a few common pelvic neuropathic conditions below.

\section{Diagnosis}

\section{A. History}

In practice, diagnosis of many cases of abdomino-pelvic neuropathic pain occurs predominantly following a recent surgical procedure. Inadvertent suture ligation, anatomical compression (even from benign sources such as pants or girdles), alterations in the perineural environment secondary to metabolic changes (such as diabetes mellitus) all have been described in cases where treatment of the presumed underlying issue resolved the patient's symptoms. Outside of the perioperative period, gynecologists will mainly confront probable neuropathic pain in rare circumstances: when it presents as endometriosis invading into pelvic nerves or as spontaneous pain involving compression of pelvic nerves such as branches of the obturator, pudendal, or lateral femoral cutaneous nerves. In contrast, women who present with the more common facial or distal extremity neuropathies should be referred to a neurologist for management. Superficial perineal pain (vulvodynia and pudendal neuralgia) have been suggested to be neuropathic pain conditions as well, but the research on nerve involvement is limited, and the exact mechanisms may be a combination of chronic mucosal inflammation and hormone or infection-mediated peripheral sensitization, rather than overt nerve disease. ${ }^{29-30}$

If the pain is presenting following a recent gynecological procedure, the clinician should take a thorough surgical history, focusing particularly on prior transverse abdominal incisions (hysterectomies, inguinal herniorrhaphy, and appendectomies) that place the iliohypogastric, ilioinguinal and genitofemoral nerves at risk. ${ }^{31}$ For perineal and deep pelvic/vaginal pain, both natural and operative vaginal delivery as well as vaginal prolapse and anti-incontinence procedures (cystocele or rectocele repair, vaginal vault suspension, midurethral slings) are associated specifically with neuropathic pain in the pudendal nerve distribution. ${ }^{32,33-35}$ Widely utilized and validated questionnaires exist to screen for neuropathic pain conditions such as the Leeds assessment of neuropathic symptoms and signs (LANSS), but should be paired with results from the clinical exam. ${ }^{36-37}$ Other questionnaires such as the McGill Pain Inventory can monitor progress and regression quantitatively. ${ }^{38}$ Inquiring about comorbid psychological disturbances (mood, anxiety) should be performed in concert with diagnosis of neuropathic pain because it is well established neuropathic pain with disability is correlated with catastrophization. ${ }^{39-40}$

Beyond sensory input, many of the pelvic nerves contain motor branches and damage can impair certain functions. Assessment of bowel and bladder function including incontinence may reveal potential pudendal nerve dysfunction. Pain after defecation (several minutes to one hour) is a positive sign for pudendal neuralgia according to the Nantes criteria (Table 1). ${ }^{41}$

\section{B. Clinical exam}

A gynecologist can at least begin the initial workup of neuropathic pain with two simple tools: a wooden cotton swab and a dermatomal map of the abdomino-pelvic region. Clinical examination by testing the response to a light touch (such as a soft cotton swab) is the best initial test for identifying probable neuropathic pain. Sites where pain is produced by light touch should be documented as allodynic. Evaluation should begin with sites adjacent to where the pain is reported and then gradually moving towards the site because touch of the painful site can trigger allodynia in adjacent sites, obscuring the diagnostic evaluation. ${ }^{42}$ While gynecologists will generally limit their testing to response to mechanical sensitivity, neuropathy can also result in alterations in thermal sensitivity. ${ }^{43}$ Indeed, cold-induced pain 
can be tested by a drop of acetone on the suspected region and visual analogue scores of $3 / 10$ and greater are considered possible evidence of neuropathic pain. ${ }^{44}$

Beyond the general diagnosis of "neuropathic pain," dermatopic mapping of pain is potentially useful for specifically identifying the affected nerve. The identification of sites with hyposensitivity after confirmed disc herniations has helped decipher the representation of the pelvic dermatome. ${ }^{45}$ The representation of the dermatome shown in Figure 1 may serve as a guide, but variation in the dermatome is known. ${ }^{31,46}$ While this aspect of physical examination is not as familiar to many gynecologists, more frequent utilization would be in the best interest of patients. Indeed, a pelvic surgeon can provide the necessary comfort and expertise with pelvic/perineal examination to embolden a reluctant pain specialist or neurologist into performing a joint evaluation in more confusing cases.

With regards to pelvic neuropathic pain, injury to any peripheral nerve (pudendal, genitofemoral, ilioinguinal, etc) or plexus (coccygeal, lumbar, hypogastric, etc) may elicit sustained pain. The degree of spread into adjacent areas, or of spontaneous pain to appear in contralateral, unprovoked sites should be discretely queried. Evidence of autonomic abnormalities such as erythema, or less commonly sweating, may suggest central components to the pain, and may point to a need for central agents to successfully abolish pain. Pins and needles-type sensation following compression over a suspected entrapped nerve is known as Tinel's sign, and may suggest local neural compression exists that may be amenable to surgical release. ${ }^{47-48}$ Abdominal wall nerves are commonly involved in abdominopelvic pain and the ilioinguinal (L1-L2), iliohypogastric (T12-L1), and genitofemoral nerve (L1-L2) all can be injured by compression or surgical ligation. Much anatomic variability exists with the course of the ilioinguinal nerve, but it can innervate the superomedial thigh, mons pubis and labium majus. ${ }^{49}$ Pain in the abdominal region adjacent to the groin at the symphysis pubis and mons is suggestive of either genitofemoral or iliohypogastric involvement.

Pelvic and perineal peripheral branches likewise can be sources of pain. Pain exacerbated with sitting should direct assessment towards the perineal branches of the ilioinguinal, genitofemoral, pudendal or lateral femoral cutaneous nerves (LFCN, L2-L3). Recent diagnostic criteria have been proposed for perineal/pudendal nerve syndromes; however, these still require validation (Table 1). ${ }^{41}$ The two divisions to consider are the posterior branches of the lateral femoral cutaneous nerve (LFCN, L2-L3) and the pudendal nerve (S2-S4). LFCN compression under the inguinal ligament can result in medial tight pain and over to the adjacent labium majus. ${ }^{49}$ The pudendal nerve dermatome extends over the labia, perineum and anorectal region. Palpation transvaginally along Alcock's canal may reproduce the reported pain with pudendal involvement, although concomitant muscle or connective tissue dysfunction may also be present. Obturator nerve branches (L2-L4) supply mainly the medial thigh, but transobturator sling placement has been linked to both thigh and groin pain suggesting variation in nerve distribution. ${ }^{50-51}$ Physical examination of the surrounding musculature both at rest and during contraction (hip abduction/adduction and flexion/extension) can help in localizing myofascial causes, and is also important to distinguish muscle spasm separately from neuropathic pain. Taut bands or trigger points are characteristic findings more suggestive of myofascial involvement, and trigger point injections with local anesthetic directly into the affected areas can simultaneously achieve diagnostic and therapeutic goals.

If lifting the patients leg 30-70 degrees while lying down on the exam table induces pain (also known as Lasègue's sign), this is a sign of lumbar or sacral herniation with relatively high ( $90 \%)$ sensitivity. ${ }^{52}$ Evaluation of knee and ankle reflexes also is helpful to rule out lumbar disc herniation. ${ }^{53}$ 


\section{Testing}

To enhance specificity, many experts routinely employ diagnostic nerve blocks, particularly with readily accessible peripheral nerves such as the ilioinguinal, the lateral femoral cutaneous, and the pudendal (via a transvaginal approach) ${ }^{54-55}$ How best to perform these blocks remain controversial due to the previously noted variability in pelvic dermatopic organization and the difficulty of precisely placing these agents into the correct plane, leading some to suggest use of ultrasound or nerve stimulators. ${ }^{56}$ This is covered more under the treatment section.

While gynecologic surgeons should easily gain comfort in performing abdominal or perineal nerve blocks, more sophisticated testing can be conducted by a neurologist. Modern quantitative sensory testing can apply precise thermal or electrical stimuli to characterize nerve, electromyographic, and cortical evoked potentials that quantify and potentially localize the site of impairment. ${ }^{57}$ At present its clinical utility remains uncertain as its superiority to conventional bedside examination remains unproven. While some widespread central pain conditions have demonstrated consistent deficits on QST, future work is needed to validate its specific ability to evaluate nerve damage in pelvic pain conditions. Normative values for vaginal sensation have been determined that could allow for future comparisons, and impairments in tactile thresholds have been reported in women with suspected pudendal neuropathy. ${ }^{58-59}$ In the setting of comorbid visceral dysfunction, nerve conduction velocities can be specifically used to verify the existence of pudendal neuropathy-induced fecal incontinence. ${ }^{60}$ Decreased latencies are observed in pudendal nerve with idiopathic (neurogenic) fecal incontinence. ${ }^{61}$ However, generalizing results outside of specialty labs has proven to be an obstacle in using these techniques widely.

\section{Treatment}

All patients experiencing chronic pelvic pain should be given benefits of comprehensive multimodal and multidisciplinary pain management, which refers to interventional nerve blocks, surgical interventions, including decompression of entrapped nerves, treatment with medication proven its efficacy in treatment of neuropathic pain in general, physical therapy modalities, psychological counseling and training and treatment with complementary alternative medicine. In this review we will focus on nerve blocks, decompressive surgical interventions and medication management.

\section{A. Neural Blockade}

Nerve blocks should be considered the first step in managing a compressed nerve for because they can provide diagnostic information while providing acute pain relief. For many of the peripheral neuropathic pain disorders of the abdomen and pelvis, nerve blocks using local anesthetic, with or without steroids, are used to reduce the spontaneous ectopic activity of the involved nerve. Particularly for presumed pudendal nerve pain and vulvar pain, a series of monthly local anesthetic blocks have reduced symptoms in small, uncontrolled studies. ${ }^{62}$

Although high quality evidence is limited, many clinicians view a clinically meaningful degree of improvement (as interpreted by the patient, persisting around two to four hours depending on which anesthetic is used) following a block to warrant a series of repeated blocks. An interval separated by a few weeks to a month is generally accepted. The occasional patient will experience dramatic, prolonged reduction of symptoms. In Arner's original study, 18/38 patients experienced relief exceeding 12 hours following each bupivicaine block. These patients had a wide variety of mononeuropathies distributed across different segmental dermatomes. ${ }^{63}$ The exact agent, volume, and whether to use ultrasound guidance or a nerve stimulator to guide the block remain unresolved questions. We typically 
inject in the office either bupivicaine $0.25 \%$ or lidocaine $1 \%$, buffered with sodium bicarbonate, and place a total of $2-3 \mathrm{~mL}$ with a 25 gauge needle into the path of the involved nerve. In particular with pudendal neuropathy some practitioners prefer a $\mathrm{CT}$ guided approach transgluteally versus the classic obstetrical transvaginal injection approach medial to the ischial spine, but evidence is predominantly anecdotal and limited to a select group of specialized centers globally. ${ }^{64}$ Beyond treatment, blocks have been taken for granted to represent an effective prognosticator of surgical outcome for decades. Nevertheless, it has been recently demonstrated that pain scores after diagnostic nerve block predicts outcome after surgical management of neuroma. ${ }^{65}$ Therefore, the utilization of neural blocks and subsequent results should be seriously considered before attempting higher risk interventions if a discrete lesion is suspected.

\section{B. Decompressive and surgical interventions}

When an acute mononeuropathy is suspected, aggressive decompressive efforts by physical therapy or surgery may be the most ideal treatment after conservative approaches have failed. In the ideal setting, an anatomical cause for neuropathic pain can be identified and reversed. Sadly, the published literature is sparse with reports of treatment of such conditions following pelvic surgery. Nevertheless, several case reports warrant mention. The best example is acute ilioinguinal or iliohypogastric nerve entrapment following fascial closure of abdominal wall incisions, such as with inguinal herniorrhaphy, pfannenstiel incisions, or even lateral endoscopic port closure. ${ }^{66}$ In the past year we have seen two cases of acute unilateral ilioinguinal nerve entrapment following routine laparoscopy that resolved following removal of the fascial stitches within a week of the initial surgery. Both failed an aggressive initial attempt at nonsurgical medical management. Similar relief has been described with release of an entrapped branch of the pudendal nerve a year after cystocele surgery and in two patients who potentially had lumbosacral nerve roots compromised at time of uterosacral vault suspension that responded to prompt suture removal within two weeks of the original surgery. ${ }^{32,}{ }^{67}$ How long to wait before attempting surgical release of an acutely entrapped nerve is largely unknown. Many cases clearly do resolve with observation and pain control, and clearly a dialogue with the patient will guide how quickly this decision is made.

The surgical management of pudendal neuropathic pain deserves separate mention. Surgical decompression of the nerve aims to free it from a compressed position between the sacrospinous and sacrotuberous ligament. The predominant approaches have been described through either the transgluteal or transischiorectal fossa by two separate French teams. ${ }^{68-69}$ Robert and colleagues have published a small unblinded controlled trial that mirrors their larger general experience with several hundred patients, which suggests that $70 \%$ of patients will report improvement, but up to $30 \%$ of cases will report unchanged or worsened perineal pain. ${ }^{68}$ Patient selection is critical, so these teams have generally reserved surgical management to those who have a partial response to initial conservative measures such as avoiding sitting, and a series of nerve blocks into the pudendal distribution.

These small studies suggest that prompt recognition and release of potential nerve entrapment after surgery can be effective, but that further research is needed. Particularly for pudendal nerve release surgery, referral to a specialist may be best, given the limited experience most gynecologists will have with these surgical approaches. Unfortunately, failure rates and improvement over conservative management for these revision procedures are unknown based on the lack of comparative studies with any significant long-term follow-up. Similarly, small case studies have suggested either abdominal wall or retroperitoneal ligation of injured ilioinguinal, iliohypogastric, or genitofemoral nerves can be effective when a release is not feasible. ${ }^{70-71}$ An important caveat is that in a subset of 
patients ligation can produce sustained deafferentation pain which can be equally if not more devastating. ${ }^{72}$

In specialty pain clinics a variety of more aggressive interventions have been described to attempt to alter aberrant pain processing at all potential targets of the neuraxis- including radiofrequency ablation of peripheral nerves, lumbar sympathectomy or stimulation of the peripheral nerve, spinal cord, brainstem, or cerebral cortex. Unfortunately, adequately powered, pelvic pain-specific randomized controlled trials are generally lacking and extrapolating from a small number of case series to general practice is risky given the wide potential for adverse outcomes when targeting neural structures involved in critical homeostatic processes. ${ }^{73-76}$ Given the risk profile, we would suggest to most practicing gynecologists, when nerve blocks and straightforward surgical revision are not an option or prove effective, patients be expeditiously offered a combination of medical and alternative strategies to achieve symptom control before choosing more drastic measures.

\section{Medical Management}

Pharmacological therapy is used frequently for neuropathic pain, although the specific data for pelvic pain disorders is also quite limited. Unfortunately, only about half of patients experience clinical relief in randomized trials on medications, and frequently only partial relief. The classic diabetic polyneuropathy and post-herpetic mononeuropathies are generally treated with tricyclic antidepressants or atypical antidepressants and anticonvulsants. ${ }^{77-83}$ The exact mechanisms by which these drugs provide pain relief is not entirely understood, but in part likely involves modulation of neuronal hypersensitivity. Of note, multiple randomized controlled trials have shown that lamotrigine, an anticonvulsant, does not appear to be effective for a number of neuropathic pain conditions. ${ }^{84}$ Still, gynecologists should feel comfortable prescribing these medications, as long as they educate patients about the potential central nervous system side effects, which generally resolve with withdrawal of the medicine (see Table 2 for suggested dosages and side effects).

For abdominal wall nerve entrapment syndromes there are only a few case reports reporting relief with anticonvulsants or antidepressants. ${ }^{85-86}$ Open label trials of anticonvulsants and antidepressants for vulvar pain and for generalized pelvic pain have shown conflicting results. ${ }^{87-90}$ One randomized controlled trial has shown better pain relief in women with chronic pelvic pain with gabapentin than amitriptyline, but this heterogeneous group of vulvar and abdominal pain sufferers did not have neuropathic pain explicitly evaluated. ${ }^{91} \mathrm{In}$ contrast, Foster and colleagues have recently found that treatment of vulvodynia with desipraimine (with or without topical xylocaine) improved symptoms but not over placebo. ${ }^{92}$ Practically speaking, slow titration of these medications, and consideration of adding a second agent from a different class when a first is inadequate, are standard approaches to managing neuropathic pain.

Many women will have already tried nonsteroidal antiinflammatories to self-manage neuropathic pain, but unfortunately the data on efficacy is limited. ${ }^{93}$ Many patients will request stronger short-acting opioids to manage these pain syndromes. Level 1 evidence exists that opioids produce superior analgesia to placebo in neuropathic pain over short periods of time, but these have not been explicitly studied in abdomino-pelvic neuropathic pain conditions. Chronic utilization is complicated by multiple side effects, least of which are effects on visceral functions such as constipation. ${ }^{94-95}$ These should be judiciously used in a time-limited fashion and in combination with other therapies in our judgment. Localized peripheral nerve disorders may also be treated with the application of topical local anesthetics (lidocaine trandermal patches).${ }^{96-97}$ Similarly, topical capsaicin may also be effective. ${ }^{98-99}$ 


\section{Alternative Approaches}

In the absence of effective treatment more than $40 \%$ of patients with chronic pain seek complementary and alternative medical approaches. ${ }^{100}$ These obviously are beyond the training of an ob/gyn but skilled practitioners such as physical therapists and chiropractors should be readily identified in many communities. Manual techniques such as physical therapy pose minimal risk, and may be appropriate when suspected concomitant myofascial dysfunction is present (such as the presence of muscle spasm) that plausibly is contributing to nerve dysfunction. Connective tissue release, embedded in many physical therapy programs, may produce an effect by resolving ectopic nerve activity. These modalities can be difficult to standardize, unfortunately. While basic research has demonstrated exercise is beneficial for peripheral neuropathy and related chronic muscle pain additional clinical research is required to prove its efficacy. ${ }^{101-102}$

Transcutaneous electrical nerve stimulation (TENS) is often incorporated with pharmacotherapy and has good evidence for efficacy from a double-blinded, randomized controlled trial of active transvaginal TENS vs. nonactive stimulation for vulvar vestibulitis following a ten week, twice-weekly in office protocol. ${ }^{103}$ Finding the ideal settings (current, pulse duration, waveform) to achieve pain relief often require a heuristic approach and an engaged practitioner. Similarly, acupuncture may also have a role, given its efficacy in a randomized controlled trial for diabetic neuropathy. ${ }^{104}$ While other studies have supported a role for acupuncture in pain management, its ability to effectively treat abdomino-pelvic neuropathies remains to be determined. ${ }^{105-107}$

\section{E. The Reign of Empirical Management in Neuropathic Pain}

We reflect on a historical anecdote in closing: in 1863 John Hilton of London described a man with pain in whom it "was quite apparent that the cause must be associated with the perineal branch of the pudic nerve." The solution to this patient's treatment was merely having "a hole made in his chair or to use a hollow cushion." 108 This approach, which we continue to see many affected women employ, was from a prior era that put faith in nerves and their pathology--without imaging, electrical nerve testing or even nerve blocks. This brief episode highlights the fact that clinicians familiar with pelvic neuroanatomy should feel comfortable using some simple principles to judiciously manage patients with pelvic neuropathic pain. Early recognition of entrapped nerves can permit application of approaches to remove or reduce acute compression including physical therapy or acute surgical revision. Selective nerve blocks may aid in making the diagnosis of a potentially reversible process. When these initial efforts prove ineffective, the use of antidepressant and anticonvulsant type neuromodulators can be safely prescribed by gynecologists to reduce symptoms, in combination with judicious use of shorter-acting pain relievers. Evolving approaches to change aberrant nerve activity such as surgical ligation or invasive neuromodulation will require further investigation.

\section{Acknowledgments}

Dr. Tu's time preparing this work is supported by NIH grant K23HD054645.

\section{References}

1. Treede RD, Jensen TS, Campbell JN, et al. Neuropathic pain: redefinition and a grading system for clinical and research purposes. Neurology. 2008; 70:1630-5. [PubMed: 18003941]

2. Bouhassira D, Attal N, Alchaar H, et al. Comparison of pain syndromes associated with nervous or somatic lesions and development of a new neuropathic pain diagnostic questionnaire (DN4). Pain. 2005; 114:29-36. [PubMed: 15733628] 
3. Nikolajsen L, Sorensen HC, Jensen TS, Kehlet H. Chronic pain following Caesarean section. Acta Anaesthesiol Scand. 2004; 48:111-6. [PubMed: 14674981]

4. Kainu JP, Sarvela J, Tiippana E, Halmesmaki E, Korttila KT. Persistent pain after caesarean section and vaginal birth: a cohort study. Int J Obstet Anesth. 2010; 19:4-9. [PubMed: 19733050]

5. Hillis SD, Marchbanks PA, Peterson HB. The effectiveness of hysterectomy for chronic pelvic pain. Obstet Gynecol. 1995; 86:941-5. [PubMed: 7501344]

6. Brandsborg B, Nikolajsen L, Hansen CT, Kehlet H, Jensen TS. Risk factors for chronic pain after hysterectomy: a nationwide questionnaire and database study. Anesthesiology. 2007; 106:1003-12. [PubMed: 17457133]

7. Hartmann KE, Ma C, Lamvu GM, Langenberg PW, Steege JF, Kjerulff KH. Quality of life and sexual function after hysterectomy in women with preoperative pain and depression. Obstet Gynecol. 2004; 104:701-9. [PubMed: 15458889]

8. Daneshgari F, Kong W, Swartz M. Complications of mid urethral slings: important outcomes for future clinical trials. J Urol. 2008; 180:1890-7. [PubMed: 18801499]

9. Berkley KJ. Sex differences in pain. Behav Brain Sci. 1997; 20:371-80. [PubMed: 10097000]

10. Singh JA, Lewallen D. Age, gender, obesity, and depression are associated with patient-related pain and function outcome after revision total hip arthroplasty. Clin Rheumatol. 2009; 28:141930. [PubMed: 19727914]

11. Ochroch EA, Gottschalk A, Troxel AB, Farrar JT. Women suffer more short and long-term pain than men after major thoracotomy. Clin J Pain. 2006; 22:491-8. [PubMed: 16772805]

12. Aubrun F, Salvi N, Coriat P, Riou B. Sex- and age-related differences in morphine requirements for postoperative pain relief. Anesthesiology. 2005; 103:156-60. [PubMed: 15983468]

13. Uchiyama K, Kawai M, Tani M, Ueno M, Hama T, Yamaue H. Gender differences in postoperative pain after laparoscopic cholecystectomy. Surg Endosc. 2006; 20:448-51. [PubMed: 16432649]

14. Antolak SJ Jr, Hough DM, Pawlina W, Spinner RJ. Anatomical basis of chronic pelvic pain syndrome: the ischial spine and pudendal nerve entrapment. Med Hypotheses. 2002; 59:349-53. [PubMed: 12208168]

15. Sherrington, CS. The integrative action of the nervous system. New Haven: Yale University Press; 1906.

16. Erlanger J, Gasser HS. The action potential in fibers of slow conduction in spinal roots and somatic nerves. J Am Physiol. 1929; 92:43-82.

17. Tu FF, Fitzgerald CM, Kuiken T, Farrell T, Harden RN. Comparative measurement of pelvic floor pain sensitivity in chronic pelvic pain. Obstet Gynecol. 2007; 110:1244-8. [PubMed: 18055716]

18. Tu FF, Fitzgerald CM, Kuiken T, Farrell T, Harden RN. Vaginal pressure-pain thresholds: initial validation and reliability assessment in healthy women. Clin J Pain. 2008; 24:45-50. [PubMed: 18180636]

19. Giesecke J, Reed BD, Haefner HK, Giesecke T, Clauw DJ, Gracely RH. Quantitative sensory testing in vulvodynia patients and increased peripheral pressure pain sensitivity. Obstet Gynecol. 2004; 104:126-33. [PubMed: 15229011]

20. Ness TJ, Powell-Boone T, Cannon R, Lloyd LK, Fillingim RB. Psychophysical evidence of hypersensitivity in subjects with interstitial cystitis. J Urol. 2005; 173:1983-7. [PubMed: 15879797]

21. Woolf CJ. Evidence for a central component of post-injury pain hypersensitivity. Nature. 1983; 306:686-8. [PubMed: 6656869]

22. Woolf CJ, Thompson SW. The induction and maintenance of central sensitization is dependent on $\mathrm{N}$-methyl-D-aspartic acid receptor activation; implications for the treatment of post-injury pain hypersensitivity states. Pain. 1991; 44:293-9. [PubMed: 1828878]

23. Porreca F, Ossipov MH, Gebhart GF. Chronic pain and medullary descending facilitation. Trends Neurosci. 2002; 25:319-25. [PubMed: 12086751]

24. Gebhart GF. Descending modulation of pain. Neurosci Biobehav Rev. 2004; 27:729-37. [PubMed: 15019423] 
25. Reynolds DV. Surgery in the rat during electrical analgesia induced by focal brain stimulation. Science. 1969; 164:444-5. [PubMed: 4887743]

26. Richardson DE, Akil H. Pain reduction by electrical brain stimulation in man. Part 2: Chronic selfadministration in the periventricular gray matter. J Neurosurg. 1977; 47:184-94. [PubMed: 301558]

27. Sabatowski R, Schafer D, Kasper SM, Brunsch H, Radbruch L. Pain treatment: a historical overview. Curr Pharm Des. 2004; 10:701-16. [PubMed: 15032697]

28. Foo H, Mason P. Brainstem modulation of pain during sleep and waking. Sleep Med Rev. 2003; 7:145-54. [PubMed: 12628215]

29. Edwards L. New concepts in vulvodynia. Am J Obstet Gynecol. 2003; 189:S24-30. [PubMed: 14532900]

30. McKay M. Vulvodynia. Diagnostic patterns Dermatol Clin. 1992; 10:423-33.

31. Whiteside JL, Barber MD, Walters MD, Falcone T. Anatomy of ilioinguinal and iliohypogastric nerves in relation to trocar placement and low transverse incisions. Am J Obstet Gynecol. 2003; 189:1574-8. [PubMed: 14710069]

32. Bohrer JC, Chen CC, Walters MD. Pudendal neuropathy involving the perforating cutaneous nerve after cystocele repair with graft. Obstet Gynecol. 2008; 112:496-8. [PubMed: 18669778]

33. Alevizon SJ, Finan MA. Sacrospinous colpopexy: management of postoperative pudendal nerve entrapment. Obstet Gynecol. 1996; 88:713-5. [PubMed: 8841264]

34. Roth TM. Management of persistent groin pain after transobturator slings. Int Urogynecol J Pelvic Floor Dysfunct. 2007; 18:1371-3. [PubMed: 17431534]

35. Corona R, De Cicco C, Schonman R, Verguts J, Ussia A, Koninckx PR. Tension-free Vaginal Tapes and Pelvic Nerve Neuropathy. J Minim Invasive Gynecol. 2008; 15:262-7. [PubMed: 18439494]

36. Bennett M. The LANSS Pain Scale: the Leeds assessment of neuropathic symptoms and signs. Pain. 2001; 92:147-57. [PubMed: 11323136]

37. Backonja MM. Need for differential assessment tools of neuropathic pain and the deficits of LANSS pain scale. Pain. 2002; 98:229-30. [PubMed: 12098635]

38. Melzack R. The McGill Pain Questionnaire: major properties and scoring methods. Pain. 1975; 1:277-99. [PubMed: 1235985]

39. Sullivan MJ, Lynch ME, Clark AJ. Dimensions of catastrophic thinking associated with pain experience and disability in patients with neuropathic pain conditions. Pain. 2005; 113:310-5. [PubMed: 15661438]

40. Haythornthwaite JA, Clark MR, Pappagallo M, Raja SN. Pain coping strategies play a role in the persistence of pain in post-herpetic neuralgia. Pain. 2003; 106:453-60. [PubMed: 14659529]

41. Labat JJ, Riant T, Robert R, Amarenco G, Lefaucheur JP, Rigaud J. Diagnostic criteria for pudendal neuralgia by pudendal nerve entrapment (Nantes criteria). Neurourol Urodyn. 2008; 27:306-10. [PubMed: 17828787]

42. Tal M, Bennett GJ. Dextrorphan relieves neuropathic heat-evoked hyperalgesia in the rat. Neurosci Lett. 1993; 151:107-10. [PubMed: 8385757]

43. Maier C, Baron R, Tolle TR, et al. Quantitative sensory testing in the German Research Network on Neuropathic Pain (DFNS): somatosensory abnormalities in 1236 patients with different neuropathic pain syndromes. Pain. 2010; 150:439-50. [PubMed: 20627413]

44. Rasmussen PV, Sindrup SH, Jensen TS, Bach FW. Symptoms and signs in patients with suspected neuropathic pain. Pain. 2004; 110:461-9. [PubMed: 15275799]

45. Keegan JJ, Garrett FD. The segmental distribution of the cutaneous nerves in the limbs of man. The Anatomical Record. 1948; 102:409-37. [PubMed: 18102849]

46. Greenberg SA. The history of dermatome mapping. Arch Neurol. 2003; 60:126-31. [PubMed: 12533100]

47. Tinel J. Les signe du foumillement dans lesions des nerfs peripheriques. Presse Med Par. 1915; 23:385-9.

48. Moldaver J. Tinel's sign. Its characteristics and significance. J Bone Joint Surg Am. 1978; 60:4124. [PubMed: 649651] 
49. Rab M, Ebmer, Dellon AL. Anatomic variability of the ilioinguinal and genitofemoral nerve: implications for the treatment of groin pain. Plast Reconstr Surg. 2001; 108:1618-23. [PubMed: 11711938]

50. Viswanathan A, Kim DH, Reid N, Kline DG. Surgical management of the pelvic plexus and lower abdominal nerves. Neurosurgery. 2009; 65:A44-51. [PubMed: 19927077]

51. Latthe PM, Foon R, Toozs-Hobson P. Transobturator and retropubic tape procedures in stress urinary incontinence: a systematic review and meta-analysis of effectiveness and complications. BJOG. 2007; 114:522-31. [PubMed: 17362484]

52. Deville WL, van der Windt DA, Dzaferagic A, Bezemer PD, Bouter LM. The test of Lasegue: systematic review of the accuracy in diagnosing herniated discs. Spine. 2000; 25:1140-7. [PubMed: 10788860]

53. Vroomen PC, de Krom MC, Knottnerus JA. Diagnostic value of history and physical examination in patients suspected of sciatica due to disc herniation: a systematic review. J Neurol. 1999; 246:899-906. [PubMed: 10552236]

54. Starling JR, Harms BA. Diagnosis and treatment of genitofemoral and ilioinguinal neuralgia. World J Surg. 1989; 13:586-91. [PubMed: 2815802]

55. Mauillon J, Thoumas D, Leroi AM, Freger P, Michot F, Denis P. Results of pudendal nerve neurolysis-transposition in twelve patients suffering from pudendal neuralgia. Dis Colon Rectum. 1999; 42:186-92. [PubMed: 10211494]

56. Peng PW, Tumber PS. Ultrasound-guided interventional procedures for patients with chronic pelvic pain - a description of techniques and review of literature. Pain Physician. 2008; 11:215-24. [PubMed: 18354713]

57. Shy ME, Frohman EM, So YT, et al. Quantitative sensory testing: report of the Therapeutics and Technology Assessment Subcommittee of the American Academy of Neurology. Neurology. 2003; 60:898-904. [PubMed: 12654951]

58. Vardi Y, Gruenwald I, Sprecher E, Gertman I, Yartnitsky D. Normative values for female genital sensation. Urology. 2000; 56:1035-40. [PubMed: 11113756]

59. Connell K, Guess MK, La Combe J, et al. Evaluation of the role of pudendal nerve integrity in female sexual function using noninvasive techniques. Am J Obstet Gynecol. 2005; 192:1712-7. [PubMed: 15902183]

60. Hill J, Hosker G, Kiff ES. Pudendal nerve terminal motor latency measurements: what they do and do not tell us. Br J Surg. 2002; 89:1268-9. [PubMed: 12296894]

61. Kiff ES, Swash M. Slowed conduction in the pudendal nerves in idiopathic (neurogenic) faecal incontinence. Br J Surg. 1984; 71:614-6. [PubMed: 6743983]

62. McDonald JS, Spigos DG. Computed tomography-guided pudendal block for treatment of pelvic pain due to pudendal neuropathy. Obstet Gynecol. 2000; 95:306-9. [PubMed: 10674599]

63. Arner S, Lindblom U, Meyerson BA, Molander C. Prolonged relief of neuralgia after regional anesthetic blocks. A call for further experimental and systematic clinical studies. Pain. 1990; 43:287-97. [PubMed: 1705693]

64. Hibner M, Desai N, Robertson LJ, Nour M. Pudendal neuralgia. J Minim Invasive Gynecol. 2010; 17:148-53. [PubMed: 20071246]

65. Stokvis A, van der Avoort DJ, van Neck JW, Hovius SE, Coert JH. Surgical management of neuroma pain: a prospective follow-up study. Pain. 2010; 151:862-9. [PubMed: 20974520]

66. Stark E, Oestreich K, Wendl K, Rumstadt B, Hagmuller E. Nerve irritation after laparoscopic hernia repair. Surg Endosc. 1999; 13:878-81. [PubMed: 10449843]

67. Lowenstein L, Dooley Y, Kenton K, Mueller E, Brubaker L. Neural pain after uterosacral ligament vaginal suspension. Int Urogynecol J Pelvic Floor Dysfunct. 2007; 18:109-10. [PubMed: 16523246]

68. Robert R, Labat JJ, Bensignor M, et al. Decompression and transposition of the pudendal nerve in pudendal neuralgia: a randomized controlled trial and long-term evaluation. Eur Urol. 2005; 47:403-8. [PubMed: 15716208]

69. Bautrant E, de Bisschop E, Vaini-Elies V, et al. Modern algorithm for treating pudendal neuralgia: 212 cases and 104 decompressions. J Gynecol Obstet Biol Reprod (Paris). 2003; 32:705-12. [PubMed: 15067894] 
70. Ducic I, Moxley M, Al-Attar A. Algorithm for treatment of postoperative incisional groin pain after cesarean delivery or hysterectomy. Obstet Gynecol. 2006; 108:27-31. [PubMed: 16816052]

71. Giger U, Wente MN, Buchler MW, Krahenbuhl S, Lerut J, Krahenbuhl L. Endoscopic retroperitoneal neurectomy for chronic pain after groin surgery. Br J Surg. 2009; 96:1076-81. [PubMed: 19672938]

72. Sweet WH. Deafferentation pain after posterior rhizotomy, trauma to a limb, and herpes zoster. Neurosurgery. 1984; 15:928-32. [PubMed: 6514166]

73. Rhame EE, Levey KA, Gharibo CG. Successful treatment of refractory pudendal neuralgia with pulsed radiofrequency. Pain Physician. 2009; 12:633-8. [PubMed: 19461829]

74. Whiteside JL, Walters MD, Mekhail N. Spinal cord stimulation for intractable vulvar pain. A case report. J Reprod Med. 2003; 48:821-3. [PubMed: 14619652]

75. Mailis-Gagnon A, Furlan AD, Sandoval JA, Taylor R. Spinal cord stimulation for chronic pain. Cochrane Database Syst Rev. 2004:CD003783. [PubMed: 15266501]

76. Bittar RG, Kar-Purkayastha I, Owen SL, et al. Deep brain stimulation for pain relief: a metaanalysis. J Clin Neurosci. 2005; 12:515-9. [PubMed: 15993077]

77. McQuay HJ, Tramer M, Nye BA, Carroll D, Wiffen PJ, Moore RA. A systematic review of antidepressants in neuropathic pain. Pain. 1996; 68:217-27. [PubMed: 9121808]

78. Saarto T, Wiffen PJ. Antidepressants for neuropathic pain: a Cochrane review. J Neurol Neurosurg Psychiatry. 2010; 81:1372-3. [PubMed: 20543189]

79. Lunn MP, Hughes RA, Wiffen PJ. Duloxetine for treating painful neuropathy or chronic pain. Cochrane Database Syst Rev. 2009:CD007115. [PubMed: 19821395]

80. Wiffen P, Collins S, McQuay H, Carroll D, Jadad A, Moore A. Anticonvulsant drugs for acute and chronic pain. Cochrane Database Syst Rev. 2005:CD001133. [PubMed: 16034857]

81. Collins SL, Moore RA, McQuay Hj, Wiffen P. Antidepressants and anticonvulsants for diabetic neuropathy and postherpetic neuralgia: a quantitative systematic review. J Pain Symptom Manage. 2000; 20:449-58. [PubMed: 11131263]

82. Jensen TS. Anticonvulsants in neuropathic pain: rationale and clinical evidence. Eur J Pain. 2002; 6 (Suppl A):61-8. [PubMed: 11888243]

83. Tremont-Lukats IW, Megeff C, Backonja MM. Anticonvulsants for neuropathic pain syndromes: mechanisms of action and place in therapy. Drugs. 2000; 60:1029-52. [PubMed: 11129121]

84. Wiffen PJ, Rees J. Lamotrigine for acute and chronic pain. Cochrane Database Syst Rev. 2007:CD006044. [PubMed: 17443611]

85. Benito-Leon J, Picardo A, Garrido A, Cuberes R. Gabapentin therapy for genitofemoral and ilioinguinal neuralgia. J Neurol. 2001; 248:907-8. [PubMed: 11697532]

86. Rizzo MA. Successful treatment of painful traumatic mononeuropathy with carbamazepine: insights into a possible molecular pain mechanism. J Neurol Sci. 1997; 152:103-6. [PubMed: 9395132]

87. Meltzer-Brody SE, Zolnoun D, Steege JF, Rinaldi KL, Leserman J. Open-label trial of lamotrigine focusing on efficacy in vulvodynia. J Reprod Med. 2009; 54:171-8. [PubMed: 19370903]

88. Reed BD, Caron AM, Gorenflo DW, Haefner HK. Treatment of vulvodynia with tricyclic antidepressants: efficacy and associated factors. J Low Genit Tract Dis. 2006; 10:245-51. [PubMed: 17012991]

89. Harris G, Horowitz B, Borgida A. Evaluation of gabapentin in the treatment of generalized vulvodynia, unprovoked. J Reprod Med. 2007; 52:103-6. [PubMed: 17393770]

90. Brown CS, Wan J, Bachmann G, Rosen R. Self-management, amitriptyline, and amitripyline plus triamcinolone in the management of vulvodynia. J Womens Health. 2009; 18:163-9.

91. Sator-Katzenschlager SM, Scharbert G, Kress HG, et al. Chronic pelvic pain treated with gabapentin and amitriptyline: a randomized controlled pilot study. Wien Klin Wochenschr. 2005; 117:761-8. [PubMed: 16416358]

92. Foster DC, Kotok MB, Huang LS, et al. Oral desipramine and topical lidocaine for vulvodynia: a randomized controlled trial. Obstet Gynecol. 2010; 116:583-93. [PubMed: 20733439] 
93. Nalamachu S, Crockett RS, Gammaitoni AR, Gould EM. A comparison of the lidocaine patch 5\% vs naproxen $500 \mathrm{mg}$ twice daily for the relief of pain associated with carpal tunnel syndrome: a 6week, randomized, parallel-group study. MedGenMed. 2006; 8:33. [PubMed: 17406167]

94. Eisenberg E, McNicol ED, Carr DB. Efficacy and safety of opioid agonists in the treatment of neuropathic pain of nonmalignant origin: systematic review and meta-analysis of randomized controlled trials. JAMA. 2005; 293:3043-52. [PubMed: 15972567]

95. Chou R, Fanciullo GJ, Fine PG, et al. Clinical guidelines for the use of chronic opioid therapy in chronic noncancer pain. J Pain. 2009; 10:113-30. [PubMed: 19187889]

96. Meier T, Wasner G, Faust M, et al. Efficacy of lidocaine patch 5\% in the treatment of focal peripheral neuropathic pain syndromes: a randomized, double-blind, placebo-controlled study. Pain. 2003; 106:151-8. [PubMed: 14581122]

97. Galer BS, Jensen MP, Ma T, Davies PS, Rowbotham MC. The lidocaine patch $5 \%$ effectively treats all neuropathic pain qualities: results of a randomized, double-blind, vehicle-controlled, 3week efficacy study with use of the neuropathic pain scale. Clin J Pain. 2002; 18:297-301. [PubMed: 12218500]

98. Watson CP, Tyler KL, Bickers DR, Millikan LE, Smith S, Coleman E. A randomized vehiclecontrolled trial of topical capsaicin in the treatment of postherpetic neuralgia. Clin Ther. 1993; 15:510-26. [PubMed: 8364943]

99. Bernstein JE, Korman NJ, Bickers DR, Dahl MV, Millikan LE. Topical capsaicin treatment of chronic postherpetic neuralgia. J Am Acad Dermatol. 1989; 21:265-70. [PubMed: 2768576]

100. Brunelli B, Gorson KC. The use of complementary and alternative medicines by patients with peripheral neuropathy. J Neurol Sci. 2004; 218:59-66. [PubMed: 14759634]

101. Kuphal KE, Fibuch EE, Taylor BK. Extended swimming exercise reduces inflammatory and peripheral neuropathic pain in rodents. J Pain. 2007; 8:989-97. [PubMed: 17890162]

102. Bement MK, Sluka KA. Low-intensity exercise reverses chronic muscle pain in the rat in a naloxone-dependent manner. Arch Phys Med Rehabil. 2005; 86:1736-40. [PubMed: 16181935]

103. Murina F, Bianco V, Radici G, Felice R, Di Martino M, Nicolini U. Transcutaneous electrical nerve stimulation to treat vestibulodynia: a randomised controlled trial. BJOG. 2008; 115:116570. [PubMed: 18715435]

104. Abuaisha BB, Costanzi JB, Boulton AJ. Acupuncture for the treatment of chronic painful peripheral diabetic neuropathy: a long-term study. Diabetes Res Clin Pract. 1998; 39:115-21. [PubMed: 9597381]

105. Rapson LM, Wells N, Pepper J, Majid N, Boon H. Acupuncture as a promising treatment for below-level central neuropathic pain: a retrospective study. J Spinal Cord Med. 2003; 26:21-6. [PubMed: 12830964]

106. Schroder S, Liepert J, Remppis A, Greten JH. Acupuncture treatment improves nerve conduction in peripheral neuropathy. Eur J Neurol. 2007; 14:276-81. [PubMed: 17355547]

107. Carlsson CP, Sjolund BH. Acupuncture for chronic low back pain: a randomized placebocontrolled study with long-term follow-up. Clin J Pain. 2001; 17:296-305. [PubMed: 11783809]

108. Antolak, SJ. Pudendal Neuralagia: Pudendal Nerve Entrapment, Alcock Canal Syndrome, and Pudendal Canal Syndrome. In: Potts, JM., editor. Genitourinary Pain and Inflammation. Totowa: Humana Press; 2008. 


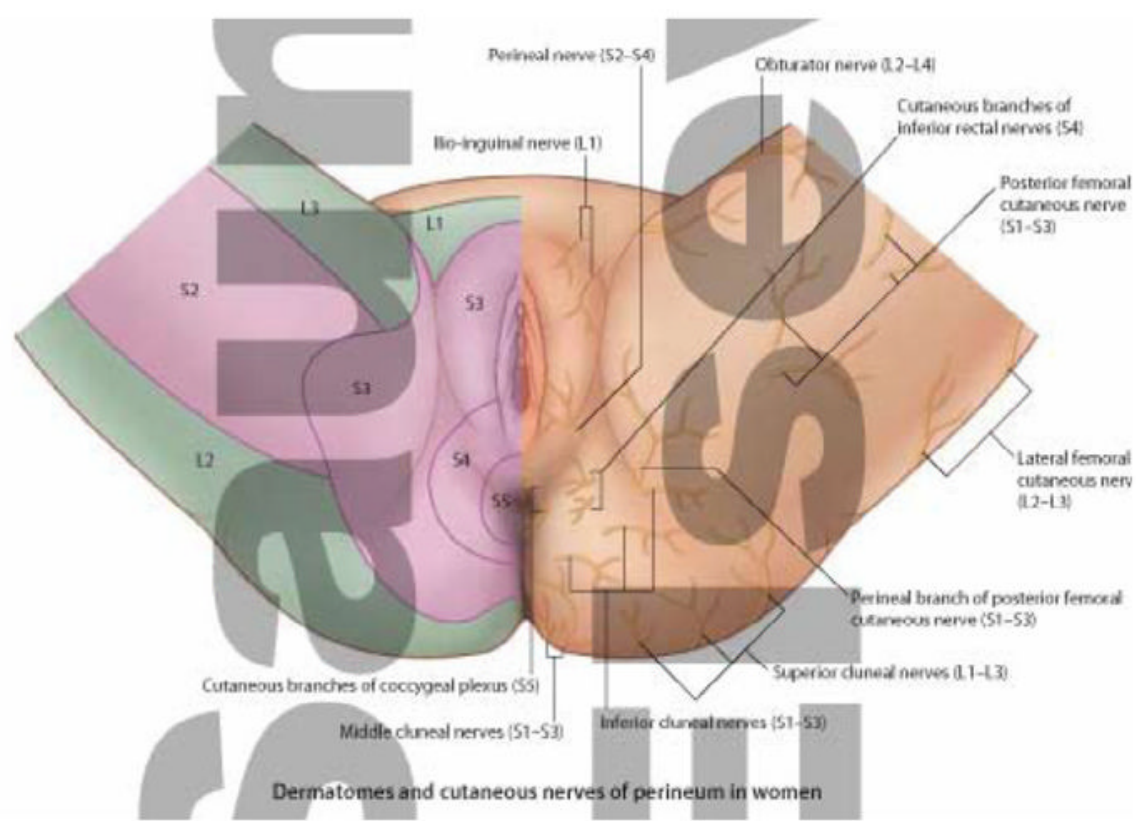

Figure 1.

Mapping the pain site in relation to the pelvic dermatome helps identify the pathological nerves. 


\section{Table 1}

\section{Nantes criteria for pudendal neuralgia}

\section{Inclusion Criteria}

Pain in the area innervated by the pudendal nerves extending from anus to clitoris

Pain more severe when sitting

Pain does not awaken patients from sleep

Pain with no objective sensory impairment

Pain relieved by diagnostic pudendal block

\section{Complementary Diagnostic Criteria}

Pain characteristics: burning, shooting, stabbing, numbing

Allodynia or hyperesthesia

Sensation of foreign body in the rectum or vagina (sympathalgia)

Pain progressively worse throughout the day

Pain predominantly unilateral

Pain triggered by defecation

Significant tenderness around ischial spine on vaginal or rectal examination

Abnormal neurophysiology testing (pudendal nerve motor latency testing) in nulliparous women

Exclusion Criteria

Pain located exclusively in the coccygeal, gluteal, pubic, or hypogastric area (without pain in the area of distribution of pudendal nerve)

Pruritus

Pain exclusively paroxysmal

Abnormality on the imaging test (magnetic resonance imaging, CT, and others), which can account for the pain

\section{Associated Signs}

Buttock pain (area around ischial tuberosity) with sitting

Referred sciatic pain

Pain referred to the medial side of the thigh

Suprapubic pain

Urinary frequency or pain with full bladder

Pain after orgasm

Dyspareunia or pain after intercourse

Normal pudendal nerve motor latency

Modified from 41 
Table 2

Dosing recommendations for representative agents used in neuropathic pain

\begin{tabular}{|c|c|c|}
\hline Class & Suggested dosing guidelines & Side effects \\
\hline $\begin{array}{l}\text { Tricyclic antidepressants } \\
\text { (nortryptiline, desipramine, } \\
\text { amitryptiline, imipramine }{ }^{a} \text { ) }\end{array}$ & $\begin{array}{l}\text { Start } 10-25 \mathrm{mg} \text { qhs, can increase by } 10-25 \mathrm{mg} \text { every } 4-7 \text { days as } \\
\text { tolerated to effect or maximum dosage of } 150 \mathrm{mg} \text {, although selected } \\
\text { patients may tolerate higher doses (suggest obtain pharmacology } \\
\text { consult); some patients will tolerate divided dosing morning/evening } \\
\text { better }\end{array}$ & $\begin{array}{l}\text { Dry mouth, somnolence, } \\
\text { dizziness, blurry vision, } \\
\text { constipation, arrhythmia (check } \\
\text { pre-treatment EKG in patients } \\
\text { above age } 40 \text { ) }\end{array}$ \\
\hline \multicolumn{3}{|l|}{$\begin{array}{l}\text { Selective serotonin/ } \\
\text { norepinephrine reuptake } \\
\text { inhibitors }\end{array}$} \\
\hline duloxetine & $\begin{array}{l}\text { Start } 30 \mathrm{mg} \text { qd, increase to } 60 \mathrm{mg} \text { qd after } 7 \text { days, maximum of } 60 \\
\text { mg BID }\end{array}$ & $\begin{array}{l}\text { Dizziness, fatigue, nausea, } \\
\text { somnolence, dry mouth, } \\
\text { serotonin syndrome, constipation }\end{array}$ \\
\hline venlafaxine & $\begin{array}{l}\text { Start } 37.5 \mathrm{mg} \text { qd or BID, increase by } 75 \mathrm{mg} \text { weekly, to effect or max } \\
225 \mathrm{mg} \text { qd }\end{array}$ & $\begin{array}{l}\text { Sweating, weight loss, reduced } \\
\text { appetite, nausea, dry mouth, } \\
\text { dizziness, somnolence, elevated } \\
\text { blood pressure, arrhythmias }\end{array}$ \\
\hline \multicolumn{3}{|l|}{ Anticonvulsants } \\
\hline gabapentin & $\begin{array}{l}300 \mathrm{mg} \text { qhs, increase by } 300 \mathrm{mg} \text { every } 4-7 \mathrm{~d} \text { until effective or up to } \\
600-900 \mathrm{mg} \text { TID, in older patients or drug sensitive, consider } \\
\text { starting/increasing by } 100 \mathrm{mg} \text {. Some patients may find BID dosing } \\
\text { better with the majority of the dosing at night. }\end{array}$ & $\begin{array}{l}\text { Dizziness, somnolence, blurry } \\
\text { vision, fever, hostile behavior }\end{array}$ \\
\hline pregabalin & $\begin{array}{l}75 \mathrm{mg} \text { BID, increase by } 75 \mathrm{mg} \text { BID every } 4-7 \text { days up to effect or } \\
300 \mathrm{mg} \text { BID }\end{array}$ & $\begin{array}{l}\text { Weight gain, somnolence, } \\
\text { dizziness, blurry vision, impaired } \\
\text { thinking }\end{array}$ \\
\hline topiramate & $\begin{array}{l}\text { Start } 50 \mathrm{mg} \text { BID increase weekly by } 50-100 \mathrm{mg} \text { up to } 200 \text { to } 400 \\
\mathrm{mg} / \text { day in two divided doses }\end{array}$ & $\begin{array}{l}\text { gastrointestinal, diarrhea, loss of } \\
\text { appetite, nausea, weight loss, } \\
\text { dizziness, paresthesia, impaired } \\
\text { concentration, somnolence, } \\
\text { blurred vision, fatigue }\end{array}$ \\
\hline \multicolumn{3}{|l|}{ Topical agents } \\
\hline $8 \%$ capsaicin patch & $\begin{array}{l}\text { single 60-minute application of up to } 4 \text { patches every } 3 \text { months as } \\
\text { needed - must be limited to area identified by physician as } \\
\text { hyperalgesic; do not apply more frequently than every } 3 \text { months, } \\
\text { wear gloves while handling }\end{array}$ & $\begin{array}{l}\text { Pain during treatment, skin rash, } \\
\text { blood pressure elevation during } \\
\text { treatment }\end{array}$ \\
\hline $5 \%$ lidocaine patch & $\begin{array}{l}\text { Apply patch (cut to appropriate size) to affected skin up to } 12 \text { hours/ } \\
24 \text { hour period }\end{array}$ & $\begin{array}{l}\text { Local skin irritation, very rare } \\
\text { systemic lidocaine toxicity (light- } \\
\text { headedness, dizziness, } \\
\text { drowsiness, tinnitus, blurred or } \\
\text { double vision, bradycardia, } \\
\text { hypotension) }\end{array}$ \\
\hline
\end{tabular}

${ }^{a}$ Amitryptiline, imipramine have higher side effects; BID - twice daily, QD - once daily, QHS - at night 